\title{
Tamarind seed polysaccharide (TSP) uses in ophthalmic drug delivery
}

\author{
Matheus Augusto de Castro ${ }^{1 *}$ (D), Wallace Mateus Prata ${ }^{2}$, Armando Silva-Cunha ${ }^{1}$ (D) \\ ${ }^{1}$ Department of Pharmaceutical Products, Faculty of Pharmacy, Universidade Federal de Minas Gerais, Belo Horizonte, MG, \\ Brasil \\ ${ }^{2}$ Research and Development Department, Fundação Ezequiel Dias, Belo Horizonte, MG, Brasil \\ *Corresponding author: matheuscastro123@hotmail.com
}

\begin{abstract}
At present, ophthalmic drug delivery remains a major challenge, given the eye's protective structure and susceptibility to irritation, resulting in poor patient adherence. In order to overcome these constraints, new formulations are continually being developed. The inclusion of Galactoxyloglucan (Tamarind seed polysaccharide (TSP) in such formulations, a natural substance extracted from the seeds of Tamarindus indica, has shown great potential due to its physicochemical properties, high biocompatibility and safety profile. Such properties, have led to its use in formulations for the treatment of dry eye disease, glaucoma, and bacterial keratitis, as well as in dilating eye drops used in eye examinations. In this article, we highlight the most recent TSPbased ophthalmologic formulations, which indicate that this polymer is a strong candidate to reduce adverse effects, improve patient tolerability and drug bioavailability.
\end{abstract}

Keywords: TSP. Galactoxyloglucan. Tamarind. Drug Delivery. Ophthalmology.

\section{How to cite}

Castro MA, Prata WM, Silva-Cunha A. Tamarind seed polysaccharide (TSP) uses in ophthalmic drug delivery. Rev Ciênc Farm Básica Apl. 2022;43:e757. https://doi.org/10.4322/2179-443X.0757

\section{INTRODUCTION}

Tamarind (Tamarindus indica) is a medium-sized evergreen tree native to Africa with a history of use in traditional medicine across tropical Asia. It is cultivated as a commercial crop on a large scale throughout a number of different countries in tropical regions including India, Thailand, Brazil, Mexico and the United States (Figure 1), with annual fruit production reaching up to 275 tonnes in sub-tropical countries alone ${ }^{1}$. According to research, each part of the tree contains different components that are used in a number of applications ${ }^{2}$ including the food, clothing, and pharmaceutical industries, and also aid in environmental matters ${ }^{3}$. 


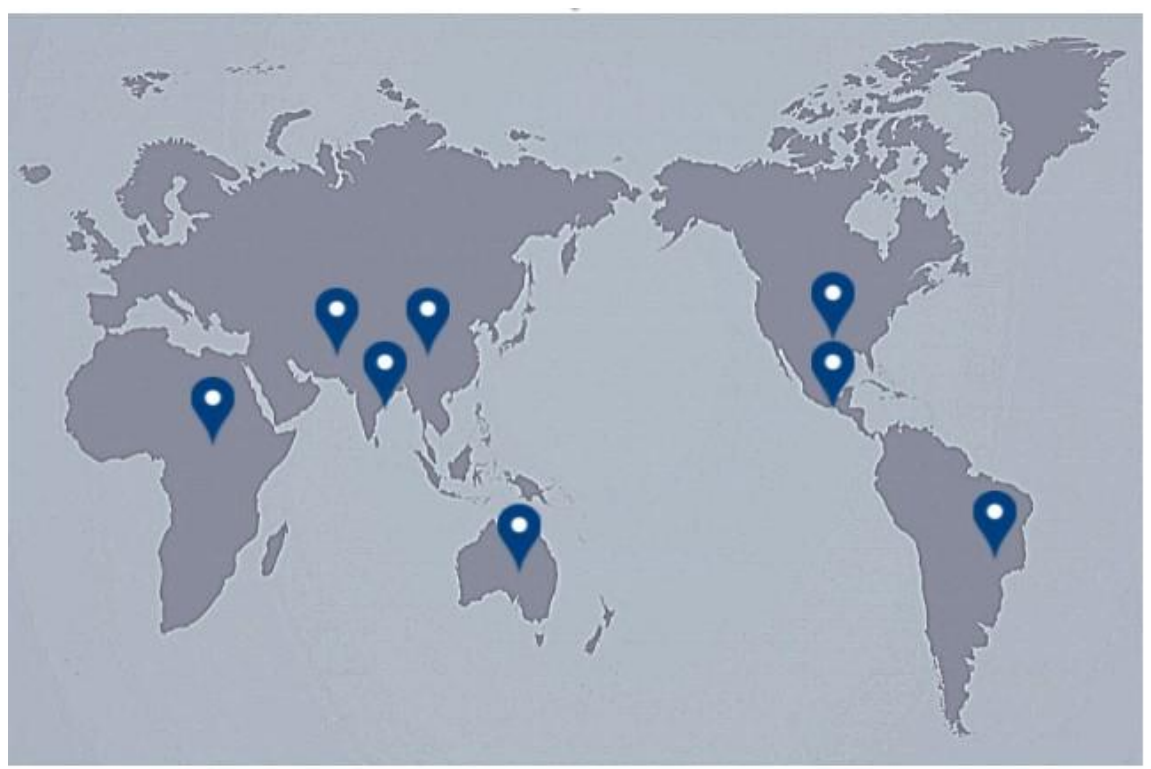

Figure 1. Tamarindus indica global distribution. The blue arrows indicate the countries in which Tamarind is cultivated.

Pharmacological interest in tamarind seed and its components (TSP) first arose with the discovery of their use in traditional medicine for the treatment of diarrhea, dysentery and bleeding, and intensified following the identification of many active constituents ${ }^{2,4}$. TSP, also known as galactoxyloglucan, is composed of the monomers glucose, galactose and xylose in a 3:1:2 ratio, with a molecular weight of roughly $52 \mathrm{kDa}$ (Figure 2). According to literature, TSP is hydrophilic, stable over a wide $\mathrm{pH}$ range, has no ionic charge, and is neither toxic nor carcinogenic, making it an excellent candidate for use in pharmaceutical preparations ${ }^{5}$. In this article we will demonstrate TSP's potential for use in ophthalmic formulations, especially for those diseases/conditions in which TSP's properties prove especially useful such as: dry eye disease (DED), glaucoma, bacterial keratitis, in addition to improving the performance of mydriasis stimulants used in clinical examinations.

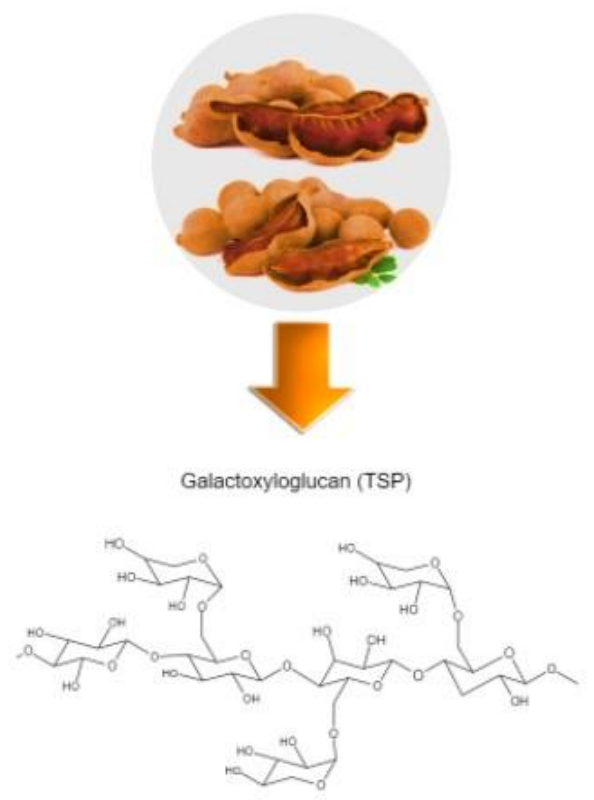

Figure 2. TSP (Galactoxyloglucan) Chemical structure. 


\section{OPHTHALMIC POTENTIAL OF TSP}

Several findings have verified TSP's beneficial properties. Historically, TSP has been used throughout Asia in healing skin wounds, and in intestinal and ocular drug delivery ${ }^{6-}$ ${ }^{8}$. TSP has ideal properties for ocular administration, such as a tendency to swell, favouring ocular bioadhesion, non-Newtonian rheological behaviour and a ferning pattern similar to natural tear film². Furthermore, TSP is a "mucin-like" compound, conferring properties similar to the MUC1 glycoprotein, which also provides mucoadhesive properties ${ }^{10}$. Studies evaluating TSP's interaction with hyaluronic acid, an excipient commonly used in ophthalmic formulations, have shown a positive synergistic relationship between the two ${ }^{11,12}$. A summary of the ophthalmic formulations to which this study refers is provided in Tables 1 and 2 below.

Table 1. TSP based formulations used in the studies evaluated and their purpose.

\begin{tabular}{ccc}
\hline TSP-based formulation & Formulation Composition & Purpose \\
\hline 1,0\% TSP/0,5\%TSP & - & Dry eye disease \\
Visine Intensiv $1 \%{ }^{\circledR}$ & $1 \%$ TSP & Dry eye disease \\
Xiloial ${ }^{\circledR}$ & $0,2 \%$ TSP and 0,2\% HA & Dry eye disease \\
$0.4 \%$ HA and & HA: Hyaluronic Acid & Dry eye disease \\
$0.2 \%$ TSP & TSP 0,5\% & Dry eye disease \\
TSP 0.5\% ${ }^{\circledR}$ & - & Glaucoma \\
2\% TSP/Timolol & - & Glaucoma \\
TSP/Timolol & - & Glaucoma \\
TSP-Alginate Pilocarpine & $0,5 \%$ TSP & Glaucoma \\
Oftagen ${ }^{\circledR}$ & - & Glaucoma \\
TSP/Prostaglandin & - & Glaucoma \\
BDNF/TSP & - & Glaucoma \\
TSP $1 \%$ & - & Bacterial Keratitis \\
0,3\% TSP-Rufloxacin & & \\
1\% TSP/Rufloxacin zwitterion & Bacterial Keratitis \\
1\%TSP/CD/Rufloxacin & CD: Cyclodextrin & \\
1\% TSP/Rufloxacin hydrochloride & & Bacterial Keratitis \\
TSP/RBO Ciprofloxacin & Rice Bran Oil & Bacterial Keratitis \\
2\% TSP/Ciprofloxacin & - & Bacterial Keratitis \\
1\% TSP & - & Mydriasis \\
Tropicamide-TSP (0,1\%) nanoparticles & - & Mydriasis \\
\hline Tromide-TSP nanoaggregates & &
\end{tabular}

Table 2. Non-TSP based formulations used in the studies evaluated and their purpose.

\begin{tabular}{ccc}
\hline Non-TSP formulations & Formulation Composition & Purpose \\
\hline Hyalistil ${ }^{\circledR}$ & Hyaluronic Acid $(0.2 \%)$ & Dry eye disease \\
Lacrisifi ${ }^{\circledR}$ & HPMC & Dry eye disease \\
Viscotears gel ${ }^{\circledR}$ & Polyacrylic acid & Dry eye disease \\
Systane UD ${ }^{\circledR}$ & HP Guar & Dry eye disease \\
Optive ${ }^{\circledR}$ & CMC & Dry eye disease \\
0.15\% HA crocin and liposomes & - & Dry eye disease \\
Etacortilen ${ }^{\circledR}$ & Sodium Phosphate Dexamethasone & Glaucoma \\
& & \\
Droptimol $^{\circledR}$ & & Glaucoma \\
& Timolol Maleate & \\
\hline
\end{tabular}


Tamarind seed polysaccharide (TSP) uses in ophthalmic drug delivery

Table 2. Continued...

\begin{tabular}{ccc}
\hline Non-TSP formulations & Formulation Composition & Purpose \\
\hline Timoptic $^{\circledR}$ & Timolol Maleate & Glaucoma \\
Glaucomol $^{\circledR}$ & Timolol Maleate & Glaucoma \\
BDNF/CMC & - & Glaucoma \\
0,3\% Ofloxacin solution & - & Bacterial Keratitis \\
0,3\% Rufloxacin solution & & \\
Rufloxacin zwitterion & & Bacterial Keratitis \\
CD/Rufloxacin & CD: Cyclodextrin & \\
Rufloxacin hydrochloride & - & Bacterial Keratitis \\
Tropicamide solution & - & Bacterial Keratitis \\
Tropicacyl & &
\end{tabular}

\section{TSP in Formulations for Dry Eye Disease (DED)}

As part of a study, an animal model for DED was developed and commercially available eye drops (Lacrisif ${ }^{\circledR}$, Hyalisti $^{\circledR}$ and Viscotears ${ }^{\circledR}$ ) containing commonly used polysaccharides were compared to $1.0 \%$ TSP in relation to their power to reduce the signs and symptoms of $\mathrm{DED}^{13}$. The study found that Hyalistil ${ }^{\circledR}$ and the eye drops developed with TSP produced type I fern structures, which are directly linked to the formulation's muco-mimetic properties. The capabilities of commercially available eye drops containing TSP (Xiloial ${ }^{\circledR}$ and $0.5 \% \mathrm{TSP}^{\circledR}$ ) were measured in an in-vitro model for dry eye disease, significantly improving inflammatory indicators, increasing the lipid layer, and enhancing mucin production within 24 hours $^{14}$.

A study was undertaken comparing the effectiveness of $0.5 \%$ and $1.0 \%$ TSP eye drops to a hyaluronate-based eye lubricant (Hyalistil $\left.{ }^{\text {Tw}}\right)^{15,16}$. In this study, in which 30 patients were monitored for 90 days, improvements in tear breakup time (TBUT) were detected in comparison to the commercial formulation, as well as reduced clinical symptoms. In addition, 1.0\% TSP achieved even better results when taking into consideration patientscore levels and the absence of any side effects, suggesting that the formulations of both concentrations of TSP are interesting candidates for further development. A further randomized clinical study involving 28 TFOS DEWS severity level 2 patients compared VISINE INTENSIV ${ }^{\circledR} 1 \%$ (commercially available eye drops containing $1.0 \%$ TSP), and SYSTANE UD ${ }^{\circledR}$ (composed of HPC-guar) ${ }^{17}$. The use of VISINE INSENTIV ${ }^{\circledR} 1 \%$ resulted in substantial Ocular Surface Disease Index (OSDI) improvement (from 50.0 to 34.1). Schrimer's test results also improved in comparison to the baseline for both eye drops (15.3 SYSTANE UD -11.9 baseline; 15.1 VISINE - 10.75 baseline).

In a comparison of Xiloial Monodose ${ }^{\circledR}(0.2 \%$ TSP and $0.2 \%$ hyaluronic acid (Farmigea, Italy)) and Optive ${ }^{\circledR}$ (Allergan, USA), comprising 49 patients with moderate DED, OSDI values demonstrated that the response to the former was twice that observed in the Optive ${ }^{\circledR}$ group $(-14,8 \text { and }-7,9 \text { respectively })^{18}$. More recently, the synergistic relationship between hyaluronic acid and TSP was further evaluated in a study involving 25 patients. The study compared two formulations: one containing $0.4 \%$ uncross-linked hyaluronic acid and $0.2 \%$ TSP (Tear A), the other containing 15\% cross-linked hyaluronic acid, crocin, and liposomes (Tear $B)^{19}$. The study found that the results of all evaluated parameters (TBUT, OSDI) showed significant statistical improvement for both formulations $(p<0.0001)$.

In a further study aimed at assessing discomfort related to disposable soft contact lenses, participants were submitted to treatment with Xiloial ${ }^{\circledR}$ for 60 days $^{20}$. Significant reduction in subjective symptoms was observed after one month of treatment, according to OSDI, with $80 \%$ of patients reaching normal scoring ( $8.5 \pm 3$ versus $20.2 \pm$ 1.6). Schirmer's test results showed a significant increase at the endpoint evident after two months of treatment ( $14.6 \pm 1.1$ versus $12 \pm 2.1)$. Overall, TSP use in formulations demonstrates several benefits for DED (Table 3). 


\section{TSP in Formulations for Glaucoma}

TSP has been used in the development of new formulations containing timolol and pilocarpine, two drugs widely used to treat glaucoma. The first of these consisted of an experimental formulation containing $5 \mathrm{mg} / \mathrm{ml}$ timolol which was developed and tested on rabbits, comparing it to the commercially available formulations Droptimol ${ }^{\circledR}$ and Timoptic $^{\circledR}$ (based on in-situ gelling system). The TSP-based formulation saw higher concentrations of timolol in tears, aqueous humour and cornea, alongside lower concentrations in plasma, indicating lower systemic absorption and greater local absorption. The formulation containing TSP reduced intraocular pressure to $3.1 \mathrm{~mm} \mathrm{Hg}$, lasting 19 hours and returning to basal values after 24 hours, suggesting a long-lasting hypotensive effect ${ }^{21}$. A novel ocular film timolol-based formulation containing TSP has also been subject to comparative testing against a regular commercial eye drop formulation (Glaucomol) 22 . According to Draize testing, this formulation was found to be non-irritant. In addition, the reduction in the animals' IOP was found to be rapid upon the eye drop formulation reaching maximum reduction (AUC $88 \mathrm{mmHg}$ ) four hours after instillation, whereas the hydrogel reduction peaked (AUC $148.425 \mathrm{mmHg}$ ) after six hours and was maintained for a total of 12 hours.

Pilocarpine was investigated through the development of an in-situ gelling system ${ }^{23}$. It released approximately $25 \%$ of the drug in the first hour and $80 \%$ during the next 12 hours, and was considered the most sustained release. In comparison to a standard eye drop solution, the longer drug activity and higher pharmacodynamic activity strongly suggest that pilocarpine bioavailability had improved.

Benzalkonium chloride (BAK) is an antibacterial substance widely used in eye dropformulations in varying concentrations. However, despite its usefulness as an excipient, it causes conjunctival and corneal damage, representing a problem for long-term therapies in patients with glaucoma associated with cellular damage and inflammation ${ }^{24}$. TSP has shown potential as an antioxidant in the food industry (decreasing visual changes in naturally sensitive products), though not as a preservative ${ }^{25,26}$. TSP's efficacy in reducing toxicity has also been subject to evaluation in a formulation containing $0.5 \%$ TSP $\left(\mathrm{Oftagen}^{\circledR}\right.$ ) as part of a prospective clinical study involving 20 patients $^{27}$. Corneal epithelial defects assessed by fluorescein staining completely disappeared after three months. Improvements in the results of clinical parameters, such as TBUT and Schirmer's test, were also detected. In addition, a further study involving 42 patients from different ophthalmic centers evaluated the benefits of using $0.5 \%$ TSP-containing eye drops in patients undergoing treatment with BAKcontaining prostaglandins (PGAs) ${ }^{28}$. After three months of daily instillation, a decline in the incidence of conjunctival hyperaemia was observed, as well as a reduction in subjective symptoms such as discomfort, swelling, and itching resulting in ocular irritation. However, an increase in Schirmer's and TBUT test results was also observed.

Recently it has been reported that the use of nerve growth factor (BDNF) can assist in retinal recovery in an animal model for glaucoma ${ }^{29}$. Evaluations of how different excipients for ocular formulations increased BDNF bioavailability in animals with lightinduced retinal damage (LE) have also been conducted ${ }^{30}$. A pre-LE BDNF/TSP topical treatment maintained fERG responses while avoiding dramatic a and b-wave shifts. Compared to vehicle-treated retinas, LE eyes treated with a single drop of BDNF/TSP revealed a substantially higher number of rows of photoreceptor nuclei. Pharmacokinetic analysis of BDNF/TSP topical eye application revealed that, six hours after application, retinal BDNF levels were higher than in the control eye and remained elevated for 12 hours. Protection against damage induced by UV radiation in cornealderived cells (SIRC) was obtained when using a formulation containing TSP. This formulation led to a decrease in the number of reactive species, significantly reducing DNA damage to corneal cells ${ }^{31}$. In conclusion, TSP would appear to offer several benefits when used in glaucoma formulations (Table 3). 
Table 3. Main studies outcomes for TSP-based products.

\begin{tabular}{|c|c|c|c|}
\hline TSP-based formulations & Non-TSP formulations & $\begin{array}{c}\text { Main outcomes for TSP } \\
\text { formulations }\end{array}$ & Reference \\
\hline & Hyalistil@ & Improved results in & \\
\hline $1.0 \% \mathrm{TSP}$ & $\begin{array}{c}\text { Lacrisifi® } \\
\text { Viscotears gel }{ }^{\circledR}\end{array}$ & $\begin{array}{l}\text { Schirmer's/ferning testing and } \\
\text { protection in rabbits with DED. }\end{array}$ & -13 \\
\hline $0.5 \%$ TSP & & Improved OSDI profile in DED & \\
\hline $1.0 \% \mathrm{TSP}$ & Hyalistili & $\begin{array}{l}\text { patients, and similar in another } \\
\text { parameters. }\end{array}$ & -15 \\
\hline VISINE INTENSIV 1\%® & SYSTANE UD® & $\begin{array}{l}\text { Both formulations improve tear } \\
\text { film stability in DED patients. }\end{array}$ & -17 \\
\hline Xiloial $^{\circledR}$ & Optive ${ }^{\circledR}$ & $\begin{array}{l}\text { Improved OSDI profile in DED } \\
\text { patients. Improvement in all } \\
\text { parameters compared to baseline. }\end{array}$ & -18 \\
\hline $\begin{array}{c}0.4 \% \mathrm{HA} \text { and } \\
0.2 \% \mathrm{TSP}\end{array}$ & $\begin{array}{l}0.15 \% \text { HA crocin, and } \\
\text { liposomes }\end{array}$ & $\begin{array}{l}\text { Equally improved results in DED } \\
\text { patients (OSDI, TBUR and } \\
\text { Schirmer's test) }\end{array}$ & -19 \\
\hline Xiloial ${ }^{\circledR}$ & Control group & $\begin{array}{l}\text { Improved OSDI, TBUT, Schirmer's } \\
\text { test, ferning test and corneal } \\
\text { damage in DED patients. }\end{array}$ & -20 \\
\hline Xiloial ${ } / T S P$ 0.5® & $\begin{array}{c}\text { Etacortilen }{ }^{\circledR} \text { Hyalistil }{ }^{\circledR} \\
\text { Optive }{ }^{\circledR}\end{array}$ & $\begin{array}{l}\text { Improved inflammatory indicators } \\
\text { and increased lipid layer (in-vitro). }\end{array}$ & -14 \\
\hline 2\% TSP/Timolol & $\begin{array}{c}\text { Droptimol }{ }^{\circledR} \\
\text { Timoptic }{ }^{\circledR}\end{array}$ & $\begin{array}{l}\text { Enhanced drug concentration in } \\
\text { site of action and prolonged IOP } \\
\text { reduction for glaucoma }\end{array}$ & -21 \\
\hline TSP/Timolol & Glaucomol® & $\begin{array}{l}\text { IOP reduction and enhanced drug } \\
\text { concentration in site of action for } \\
\text { glaucoma }\end{array}$ & -22 \\
\hline TSP-Alginate Pilocarpine & Control group & $\begin{array}{l}\text { Prolonged drug delivery in } \\
\text { glaucomatous rabbits. } \\
\text { Improved Schirmer's test and }\end{array}$ & -23 \\
\hline 0.5\% TSP (Oftagen $®) ~$ & Control group & $\begin{array}{l}\text { TBUT results. Increased sub-basal } \\
\text { nerve fibers in glaucoma patients. } \\
\text { Improved Schirmer's test and } \\
\text { TBUT results, reduced ocular }\end{array}$ & -27 \\
\hline TSP/Prostaglandin & Control group & $\begin{array}{l}\text { hyperemia and increased } \\
\text { conjunctival goblet cells in } \\
\text { glaucoma patients. }\end{array}$ & -28 \\
\hline BDNF/TSP & BDNF/CMC & $\begin{array}{l}\text { Preserved photoreceptor and fERG } \\
\text { pattern. Increased retinal BDNF } \\
\text { levels in mice. }\end{array}$ & -30 \\
\hline TSP $1 \%$ & Control group & Protection for UV-B DNA damage & -31 \\
\hline $0.3 \%$ TSP-Rufloxacin & $\begin{array}{l}\text { 0,3\% Ofloxacin } \\
0,3 \% \text { Rufloxacin }\end{array}$ & $\begin{array}{l}\text { Substantial reduction in corneal } P \text {. } \\
\text { aeruginosa and S. aureus in rabbits. }\end{array}$ & -32 \\
\hline $\begin{array}{c}\text { 1\% TSP/RUF zwitterion } \\
\text { 1\% TSP/CD/RUF }\end{array}$ & $\begin{array}{l}\text { RUF zwitterion } \\
\text { CD/RUF }\end{array}$ & $\begin{array}{l}\text { Improved drug solubilization and } \\
\text { concentration in site of action. } \\
\text { Decreased Enterobacteriaceae and }\end{array}$ & -33 \\
\hline $1 \% \mathrm{TSP} / \mathrm{RUF}-\mathrm{HCl}$ & $\mathrm{RUF}-\mathrm{HCl}$ & $\begin{array}{l}\text { Pseudomonas aeruginosa ocular } \\
\text { levels in rabbits. }\end{array}$ & \\
\hline TSP/RBO Ciprofloxacin & Control group & $\begin{array}{l}\text { Improved drug permeation } \\
\text { dependent on RBO concentration. } \\
\text { Improved activity against } E \text {. coli } \\
\text { and B. subtilis. }\end{array}$ & -34 \\
\hline 2\% TSP/Ciprofloxacin & Control group & $\begin{array}{l}\text { Improved antibacterial activity and } \\
\text { drug concentration in site of } \\
\text { action. S. aureus inhibition in eyes } \\
\text { of rabbits. }\end{array}$ & -35 \\
\hline $\begin{array}{c}\text { Tropicamide-TSP }(0.10 \%) \\
\text { nanoparticles }\end{array}$ & Tropicamide solution & $\begin{array}{l}\text { Similar results in corneal } \\
\text { permeation testing and improved } \\
\text { safety (HET-CAM) }\end{array}$ & -36 \\
\hline Tropicamide-TSP nanoaggregates & Tropicacyl ${ }^{\circ}$ & $\begin{array}{l}\text { Improved corneal permeation test } \\
\text { results and similar safety (HET- } \\
\text { CAM) }\end{array}$ & -37 \\
\hline
\end{tabular}

\section{TSP in Formulations for Bacterial Keratitis}

In order to investigate TSP's ability to increase the concentration of antibiotics in the cornea, formulations of rufloxacin either containing or not containing TSP were compared in an animal model for keratitis, in addition to a traditional formulation of oflocaxin ${ }^{32}$. TSP- 
rufloxacin administration resulted in slightly higher intraocular drug levels than rufloxacin alone, as shown by the values observed in uninfected $(4.62 \mathrm{~g} / \mathrm{ml} ; P 0.01), P$. aeruginosa-infected $(5.63 \mathrm{~g} / \mathrm{ml} ; \mathrm{P} 0.01)$, and S. aureus-infected $(6.91 \mathrm{~g} / \mathrm{ml} ; \mathrm{P}$ 0.001) eyes. In the cornea, TSPrufloxacin was slightly more effective than rufloxacin alone in regulating $P$. aeruginosa bacterial proliferation. With regard to $S$. aureus, TSP-rufloxacin administration resulted in a significant drop in corneal bacteria relative to both rufloxacin-treated and ofloxacin-treated eyes (P 0.05). A further study was conducted evaluating different formulations of rufloxacin (RUF) with TSP, namely two pH 7.2 suspensions of non-salified rufloxacin base, one of which was thickened with TSP; two pH 7.2 solutions of RUF obtained using hydroxypropyl- $\beta$ cyclodextrin (CD), one with TSP; and two pH 5.0 solutions of rufloxacin hydrochloride (RUF-HCl), one containing TSP ${ }^{33}$. In this study, the suspension containing TSP showed twice the concentration in aqueous humor compared to S-RUF (187.88 vs $67.63 \mathrm{~min} \mu \mathrm{g} / \mathrm{mL}$ ), given the viscosity potential of the polysaccharide. Additionally, $\mathrm{pH}$ levels were also shown to influence drug concentration, since the concentration was higher at $\mathrm{pH} 7.2$ when compared to the same formulation at $\mathrm{pH}$ 5.0. Rufloxacin solubilization in HP- $\beta-\mathrm{CD}(\mathrm{pH}$ 7.2) irrespective of whether or not it contained TSP, showed, poor performance in the final concentration. This could be explained by the fact that the drug interacted strongly with the cyclodextrins and that combination with the viscous agent proved a greater hinderance to drug delivery= Accordingly, the viscosity of the final formulation required further evaluation.

Recently, an emulgel formulation containing different concentrations of rice bran oil (RBO) and TSP has been developed for controlled release of ciprofloxacin ${ }^{34}$. To evaluate the formulation's effectiveness in inhibiting the growth of microorganisms, an ex-vivo corneal permeation test was performed in goats. This revealed that the drug's ability to penetrate tissue increased relative to RBO concentration. The formulation was tested against $B$. subtilis and E. coli, inhibiting microorganism development based on an increase in RBO concentration and the stabilization of TSP levels, indicating an increase in permeability and drug release into the medium.

An additional study using ciprofloxacin was conducted with the objective of developing a TSP (2\%) based ocular film formulation ${ }^{35}$. When tested for the efficacy of drug release against S. aureus, the formulation succeeded in inhibiting microbiological growth throughout the test period (48 hours) with no signs of irritation found (Draize test).

Results suggest that TSP provides for a more effective antibacterial reaction, potentially raising the antibiotic's precorneal residence period and increasing drug concentration in the cornea (Table 3).

\section{TSP in Formulations for Mydriasis}

Tropicamide - TSP (0.1\%) suspension was developed as a safe and effective alternative method of drug delivery. In comparison to the commercial formulation, the suspension scored much lower (between 0 and 1 point) in ex-vivo biocompatibility testing (HET-CAM) (between 3 and 4 points). In bioadhesion testing, the formulation adhered to $88 \%$ of the mucin $^{36}$, indicating mucoadhesive characteristics. Mydriasis improvement was addressed with a TSP/poloxamer-based nanoaggregates formulation ${ }^{37}$. The tropicamide nanoaggregates permeated the cornea more intensely in an ex-vivo study $(0.661 \%)$ than the commercial solution Tropicacyl (0.573\%), explained by its capacity to stimulate organism endocytic system and the absence of preservative in the developed formulation. However, the premise of increasing corneal permeation in future in-vivo studies remains. In bioadhesion testing, the formulation succeeded in binding to $87.35 \%$ of the mucin, a finding that is closely associated with the formulation's TSP. In addition, there was no significant score in the HET-CAM test for the developed formulation and Tropicacy ${ }^{\circledR}$, nor any relevant cytotoxic activity (Table 3). 


\section{CONCLUSION}

After careful analysis of recent articles regarding ophthalmic formulations, TSP undoubtedly shows potential to increase drug corneal permeation by prolonging precorneal retention time in eye drop formulations, therefore safely increasing patient adherence by improving ocular comfort. Further research of TSP-based ophthalmic formulations should therefore be encouraged. This paper paves the way for new research involving this natural polymer.

\section{ACKNOWLEDGMENTS}

The authors would like to thank CAPES (Coordenação de Aperfeiçoamento de Pessoal de Nível Superior) for their financial support.

\section{REFERENCES}

1. Hemshekhar M, Kemparaju K, Girish KS. Tamarind (Tamarindus indica) seeds: an overview on remedial qualities. In: Preedy VR, Watson R, Patel VB, editors. Nuts \& seeds in health and disease prevention. London: Academic Press; 2011. p. 1107-14

2. Jain AP, Bhadoriya SS, Ganeshpurkar A, Narwaria J, Rai G. Tamarindus indica: extent of explored potential. Pharmacogn Rev. 2011;5(9):73-81. http://dx.doi.org/10.4103/09737847.79102. PMid:22096321.

3. Kumar CS, Bhattacharya S. Tamarind seed : properties, processing and utilization tamarind seed: properties, processing and utilization. Crit Rev Food Sci Nutr. 2008;48(1):1-20. http://dx.doi.org/10.1080/10408390600948600. PMid:18274963.

4. Shah NC. Tamarindus indica: introduction in India and culinary, medicinal, and industrial uses. Asian Agrihist. 2014;18(4):343-55.

5. Gupta S, Jain S, Rao GK, Gupta V, Puri R. Tamarind kernel gum: an upcoming natural polysaccharide. Systematic Reviews in Pharmacy. 2010;1(1):50-4. http://dx.doi.org/10.4103/0975-8453.59512.

6. Babu PR, Thomas M, Julius A, Madhu V. Dual property of tamarind seed polysaccharide aid wound healing. International Journal of Advanced Science and Technology. 2019;28(20):113041.

7. Yusof M, Akram HB, Bero DN. Tamarind seed extract enhances epidermal wound healing. Int J Biol. 2012;4(1):81-8.

8. Durai RD, Rajalakshmi G, Joseph J, Kanchalochana SN, Hari V. Tamarind seed polysaccharide: a promising natural excipient for pharmaceuticals. Int J Green Pharm. 2012;6(4):270-8. http://dx.doi.org/10.4103/0973-8258.108205.

9. Alpizar-Reyes E, Carrillo-Navas H, Gallardo-Rivera R, Varela-Guerrero V, Alvarez-Ramirez J, Pérez-Alonso C. Functional properties and physicochemical characteristics of tamarind (Tamarindus indica L. ) seed mucilage powder as a novel hydrocolloid. J Food Eng. 2017;209:6875. http://dx.doi.org/10.1016/j.jfoodeng.2017.04.021.

10. Piqué N, Gómez-Guillén MC, Montero MP. Xyloglucan, a plant polymer with barrier protective properties over the mucous membranes: an overview. Int J Mol Sci. 2018;19(3):1-19. http://dx.doi.org/10.3390/ijms19030673. PMid:29495535.

11. Uccello-Barretta G, Nazzi S, Balzano F, Sansó M. A nuclear magnetic resonance approach to the comparison of mucoadhesive properties of polysaccharides for ophthalmic uses. Int J Pharm. 2011;406(1-2):78-83. http://dx.doi.org/10.1016/j.ijpharm.2010.12.032. PMid:21219993.

12. Uccello-Barretta G, Nazzi S, Zambito Y, Di Colo G, Balzano F, Sansò M. Synergistic interaction between TS-polysaccharide and hyaluronic acid: implications in the formulation of eye drops. Int J Pharm. 2010;395(1-2):122-31. http://dx.doi.org/10.1016/j.ijpharm.2010.05.031. PMid:20580791.

13. Burgalassi S, Panichi L, Chetoni P, Saettone MF, Boldrini E. Development of a simple dry eye model in the albino rabbit and evaluation of some tear substitutes. Ophthalmic Res. 1999;31(3):229-35. http://dx.doi.org/10.1159/000055537. PMid:10224507. 
14. Meloni M, de Servi B, Marasco D, del Prete S. Molecular mechanism of ocular surface damage: application to an in vitro dry eye model on human corneal epithelium. Mol Vis. 2011;17:11326. PMid:21245952.

15. Rolando $M$, Valente $C$. Establishing the tolerability and performance of tamarind seed polysaccharide (TSP) in treating dry eye syndrome: results of a clinical study. BMC Ophthalmol. 2007;7(5):1-8. http://dx.doi.org/10.1186/1471-2415-7-5. PMid:17394642.

16. Wadhwa S, Paliwal R, Paliwal S, Vyas S. Nanocarriers in ocular drug delivery: an update review. Curr Pharm Des. 2009;15(23):2724-50. http://dx.doi.org/10.2174/138161209788923886. PMid:19689343.

17. Jacobi C, Kruse FE, Cursiefen C. Prospective, randomized, controlled comparison of SYSTANE UD eye drops versus VISINE INTENSIV 1\% EDO eye drops for the treatment of moderate dry eye. J Ocul Pharmacol Ther. 2012;28(6):598-603. http://dx.doi.org/10.1089/jop.2012.0066. PMid:22813209.

18. Barabino S, Rolando M, Nardi M, Bonini S, Aragona P, Traverso CE. The effect of an artificial tear combining hyaluronic acid and tamarind seeds polysaccharide in patients with moderate dry eye syndrome: a new treatment for dry eye. Eur J Ophthalmol. 2014;24(2):173-8. http://dx.doi.org/10.5301/ejo.5000355. PMid:24030535.

19. Sánchez-González JM, De-Hita-Cantalejo C, Sánchez-González MC. Crosslinked hyaluronic acid with liposomes and crocin for management symptoms of dry eye disease caused by moderate meibomian gland dysfunction. Int J Ophthalmol. 2020;13(9):1368-73. http://dx.doi.org/10.18240/ijo.2020.09.05. PMid:32953573.

20. Versura P, Profazio V, Balducci N, Campos EC. Efficacy of two-month treatment with Xiloial ${ }^{\circ}$ eyedrops for discomfort from disposable soft contact lenses. Clin Ophthalmol. 2010;4(1):103541. http://dx.doi.org/10.2147/OPTH.S10448. PMid:20922039.

21. Burgalassi S, Chetoni P, Panichi L, Boldrini E, Saettone MF. Xyloglucan as a novel vehicle for timolol: pharmacokinetics and pressure lowering activity in rabbits. J Ocul Pharmacol Ther. 2000;16(6):497-509. http://dx.doi.org/10.1089/jop.2000.16.497. PMid:11132897.

22. Kulkarni GT, Sethi N, Awasthi R, Pawar VK, Pahuja V. Development of Ocular Delivery System for Glaucoma Therapy Using Natural Hydrogel as Film Forming Agent and Release Modifier. Polim Med. 2016;46(1):25-33. http://dx.doi.org/10.17219/pim/63750. PMid:28397416.

23. Mehra GR, Manish M, Rashi S, Neeraj G, Mishra D. Enhancement of miotic potential of pilocarpine by tamarind gum based in-situ gelling ocular dosage form. Acta Pharmaceutica Sciencia. 2010;52(2):145-54.

24. Rosin LM, Bell NP. Preservative toxicity in glaucoma medication: clinical evaluation of benzalkonium chloride-free 0.5\% timolol eye drops. Clin Ophthalmol. 2013;7:2131-5. PMid:24204115.

25. Natukunda S, Muyonga JH, Mukisa IM. Effect of tamarind (Tamarindus indica L.) seed on antioxidant activity, phytocompounds, physicochemical characteristics, and sensory acceptability of enriched cookies and mango juice. Food Sci Nutr. 2015;4(4):494-507. http://dx.doi.org/10.1002/fsn3.311. PMid:27386100.

26. Surati B, Minocheherhomji F. Benefits of Tamarind kernel powder: a natural polymer. Int J Adv Res (Indore). 2018;6(3):54-7. http://dx.doi.org/10.21474/IJAR01/6647.

27. Vagge A, Bonino M, Rolando M, Macrì A, Traverso CE, lester M. The utility of an artificial substitute to improve corneal sensitivity in glaucomatous patients on chronic therapy with prostaglandin analogs. J Ocul Pharmacol Ther. 2015;31(5):286-90. http://dx.doi.org/10.1089/jop.2014.0131. PMid:25974240.

28. lester M, Oddone F, Fogagnolo P, Frezzotti P, Figus M. Changes in the morphological and functional patterns of the ocular surface in patients treated with prostaglandin analogues after the use of TSP $0.5 \% @$ Preservative-Free Eyedrops: A prospective, multicenter study. Ophthalmic Res. 2014;51(3):146-52. http://dx.doi.org/10.1159/000357100. PMid:24557328.

29. Domenici L, Origlia N, Falsini B, Cerri E, Barloscio D, Fabiani C, Sansò M, Giovannini L. Rescue of retinal function by BDNF in a mouse model of glaucoma. PLoS One. 2014;9(12):e115579. http://dx.doi.org/10.1371/journal.pone.0115579. PMid:25536045. 
30. Cerri E, Origlia N, Falsini B, Barloscio D, Fabiani C, Sansò M, Ottino S, Giovannini L, Domenici L. Conjunctivally applied BDNF protects photoreceptors from light-induced damage. Transl Vis Sci Technol. 2015;4(6):1-11. http://dx.doi.org/10.1167/tvst.4.6.1. PMid:27190697.

31. Raimondi L, Lodovici M, Guglielmi F, Banchelli G, Ciuffi M, Boldrini E, Pirisino R. The polysaccharide from Tamarindus indica (TS-polysaccharide) protects cultured corneal-derived cells (SIRC cells) from ultraviolet rays. J Pharm Pharmacol. 2003;55(3):333-8. http://dx.doi.org/10.1211/002235702630. PMid:12724038.

32. Ghelardi E, Tavanti A, Davini P, Celandroni F, Salvetti S, Parisio E, Boldrini E, Senesi S, Campa M. A mucoadhesive polymer extracted from tamarind seed improves the intraocular penetration and efficacy of rufloxacin in topical treatment of experimental bacterial keratitis. Antimicrob Agents Chemother. 2004;48(9):3396-401. http://dx.doi.org/10.1128/AAC.48.9.33963401.2004. PMid:15328102.

33. Burgalassi S, Cappello B, Chetoni P, lervolino M, Monti D, Saettone MF. Rufloxacin eyedrops: effect of different formulations on ocular pharmacokinetics in rabbits. Eur J Ophthalmol. 2006;16(2):311-7. http://dx.doi.org/10.1177/112067210601600219. PMid:16703552.

34. Rawooth M, Qureshi D, Hoque M, Prasad MPJG, Mohanty B, Alam MA, Anis A, Sarkar P, Pal K. Synthesis and characterization of novel tamarind gum and rice bran oil-based emulgels for the ocular delivery of antibiotics. Int J Biol Macromol. 2020;164:1608-20. http://dx.doi.org/10.1016/j.ijbiomac.2020.07.231. PMid:32763397.

35. Mahajan HS, Deshmukh SR. Development and evaluation of gel-forming ocular films based on xyloglucan. Carbohydr Polym. 2015;122:243-7. http://dx.doi.org/10.1016/j.carbpol.2015.01.018. PMid:25817665.

36. Kaur H, Ahuja M, Kumar S, Dilbaghi N. Carboxymethyl tamarind kernel polysaccharide nanoparticles for ophthalmic drug delivery. Int J Biol Macromol. 2012;50(3):833-9. http://dx.doi.org/10.1016/j.ijbiomac.2011.11.017. PMid:22138451.

37. Dilbaghi N, Kaur H, Ahuja M, Kumar S. Evaluation of tropicamide-loaded tamarind seed xyloglucan nanoaggregates for ophthalmic delivery. Carbohydr Polym. 2013;94(1):286-91. http://dx.doi.org/10.1016/j.carbpol.2013.01.054. PMid:23544540.

\section{Authors' contributions}

MC - Data acquisition, interpretation and writing; WMP - Data acquisition and support; ASCJr Project conceptualization, funding and draft revision. 